\title{
Prefilled syringes and usability of ophthalmic viscosurgical devices
}

This article was published in the following Dove Press journal:

Clinical Ophthalmology

4 September 2014

Number of times this article has been viewed

Takuya Shiba

Hiroshi Tsuneoka

Department of Ophthalmology, Jikei University School of Medicine, Tokyo, Japan
Correspondence:Takuya Shiba

Department of Ophthalmology, jikei University School of Medicine,

3-19-18 Nishishinbashi, Minato-ku,

Tokyo, I05-846I, Japan

Tel +8 I 33433 I I I I

Fax +8 I 334331936

Email shiba@jikei.ac.jp
Purpose: To examine the influence of the configuration of prefilled syringes on the usability of ophthalmic viscosurgical devices (OVDs).

Setting: Department of Ophthalmology, Jikei University School of Medicine, Tokyo, Japan. Design: Experimental study.

Methods: The maximum force needed to extrude the whole OVD (extrusion force) was compared among viscous cohesive OVDs (OPEGAN Hi ${ }^{\circledR} 0.85 \mathrm{~mL}$ and Healon ${ }^{\circledR} 0.85 \mathrm{~mL}$ ) and very low viscosity dispersive OVDs (OPEGAN ${ }^{\circledR} 0.6 \mathrm{~mL}$ and OPEGAN $\left.{ }^{\circledR} 1.1 \mathrm{~mL}\right)$. Additionally, to exclude the influence of any differences between syringes of viscous cohesive OVDs on the extrusion force, empty syringes of the same configuration were refilled with the same products. In addition, the syringe inner surface and that of the piston attached to the tip of the plunger were measured.

Results: The extrusion force of Healon $0.85 \mathrm{~mL}(3.28 \pm 0.19 \mathrm{kgf})$ was significantly $(P<0.01)$ higher than that of OPEGAN Hi $0.85 \mathrm{~mL}(2.54 \pm 0.23 \mathrm{kgf})$. The inner syringe chamber for Healon $0.85 \mathrm{~mL}$ was vial shaped and had a built-in needle in the Luer tip, which was clearly different from OPEGAN Hi $0.85 \mathrm{~mL}$. There were no significant differences in the extrusion force between refilled syringes. The extrusion force of OPEGAN $1.1 \mathrm{~mL}(3.44 \pm 0.12 \mathrm{kgf})$ was significantly $(P<0.01)$ higher than that of OPEGAN $0.6 \mathrm{~mL}(1.63 \pm 0.06 \mathrm{kgf})$. The syringe of OPEGAN $1.1 \mathrm{~mL}$ was obviously bigger than that of OPEGAN $0.6 \mathrm{~mL}$.

Conclusion: It was confirmed that the configuration of the syringes is another determinant of the extrusion force and a factor related to the difference in usability among products that meet the same cohesive class.

Keywords: configuration, syringe, extrusion force, viscous cohesive OVDs, low viscosity dispersive OVDs

\section{Introduction}

Ophthalmic viscosurgical devices (OVDs), also called viscoelastic substances, take advantage of the viscoelasticity of sodium hyaluronate or chondroitin sulfate sodium salt, which are major components of OVDs. ${ }^{1,2}$ OVDs are used to maintain space and protect intraocular tissue during intraocular surgery, which requires precise manipulation. ${ }^{3-5}$ Surgeons select the appropriate OVD, based on its viscosity, depending on the type of surgical procedure. ${ }^{6,7}$

Almost all OVDs are available in prefilled syringes, but the syringes vary and have a different feel when held in the hand or used. OVDs of varying viscoelasticity have a different feel when extruded - even OVDs of the same cohesive class seem to have a different feel when used, especially when the force required to extrude (extrusion force) the solution differs. If the same OVDs are continuously used for every routine surgery, surgeons would not feel any problems. In addition, experienced surgeons can better handle the different feel of varying OVDs, unconsciously making 
adjustments according to the intraocular OVDs being implanted under microscope observation. On the other hand, from the authors' experience, novice surgeons and surgeons who switch from long-used OVDs or use a different cohesive OVD for each surgery find such differences a bit difficult to get accustomed to. In other words, these differences seem to have little influence in the hands of most surgeons, but some surgeons may find such differences a bit difficult to get used to. However, this matter has not been examined yet (in Japan at least).

This report focuses on the cohesive OVDs that are most commonly used. The extrusion force required for each product was measured to compare and review the configuration of prefilled syringes as another factor that might influence the extrusion force and thereby the usability of a product.

\section{Materials and methods}

\section{Investigational products}

The investigational products are shown in Table 1 and Figure 1.

The major component of OPEGAN Hi ${ }^{\circledR} 0.85 \mathrm{~mL}$ (viscous cohesive; Seikagaku Corporation, Tokyo, Japan) and Healon $^{\circledR} 0.85 \mathrm{~mL}$ (viscous cohesive; Abbott Medical Optics Inc, Santa Ana, CA, USA) has the same molecular weight. However, as they are manufactured by different companies, these products come in syringes with different configurations. OPEGAN ${ }^{\circledR} 0.6 \mathrm{~mL}$ (very low viscosity dispersive; Seikagaku) and OPEGAN Hi $0.85 \mathrm{~mL}$ use the same syringe manufactured by the same company, but the molecular weight of the major component is different. OPEGAN $0.6 \mathrm{~mL}$ and OPEGAN ${ }^{\circledR} 1.1 \mathrm{~mL}$ (very low viscosity dispersive; Seikagaku) are manufactured by the same company and meet the same standards. However, because they have a different amount, these products come in syringes of different sizes.

\section{Measurement of the extrusion force}

\section{Extrusion force required for each product}

After attaching a needle $27 \mathrm{G} \times 3 / 4^{\prime \prime}$ (Terumo Corporation, Tokyo, Japan) to each product, the maximum force needed to extrude the whole OVD was compared using the EZ test employing a compact tabletop tester (EZ-S 500N; Shimadzu Corporation, Kyoto, Japan) (extrusion speed: $18 \mathrm{~cm} / \mathrm{min}-$ ute). In Japan, investigational products are not packaged together with their own needle. Therefore, the same type of needle was attached to all products to focus the investigation on the configuration of the syringes and eliminate the influence of the needle. Measurements were taken at room temperature controlled in the range of $20^{\circ} \mathrm{C} \pm 5^{\circ} \mathrm{C}$. Six samples of each product were tested to measure the average extrusion force.

\section{Extrusion force required for refilled syringes}

In order to compare the extrusion force while excluding differences between syringes, empty syringes of the same type were refilled with the contents of OPEGAN Hi $0.85 \mathrm{~mL}$ and Healon $0.85 \mathrm{~mL}$ and the extrusion force was measured.

Table I Investigational products

\begin{tabular}{|c|c|c|c|c|c|c|}
\hline \multirow[t]{2}{*}{ Products } & \multirow{2}{*}{$\begin{array}{l}\text { Zero-shear } \\
\text { viscosity range* } \\
\text { (mPa/second) }\end{array}$} & \multirow{2}{*}{$\begin{array}{l}\text { Classification } \\
\text { of OVDs* }\end{array}$} & \multicolumn{2}{|c|}{ Sodium hyaluronate } & \multirow[t]{2}{*}{ Inactive ingredients } & \multirow[t]{2}{*}{ Manufacturer } \\
\hline & & & Conc ${ }^{\#}(\%)$ & $M W^{\#}(\mathrm{Da})$ & & \\
\hline OPEGAN $^{\circledR} 0.6 \mathrm{~mL}$ & $\begin{array}{l}10^{3}-10^{4} \\
\text { (thousands) }\end{array}$ & $\begin{array}{l}\text { Very low } \\
\text { viscosity } \\
\text { dispersive }\end{array}$ & 1 & $0.5-1.2 \mathrm{M}$ & $\begin{array}{l}\text { Sodium chloride, sodium } \\
\text { dihydrogen phosphate } \\
\text { dihydrate, dibasic sodium } \\
\text { phosphate hydrate }\end{array}$ & $\begin{array}{l}\text { Seikagaku } \\
\text { Corporation }\end{array}$ \\
\hline OPEGAN $^{\circledR}$ I.I mL & $\begin{array}{l}10^{3}-10^{4} \\
\text { (thousands) }\end{array}$ & $\begin{array}{l}\text { Very low } \\
\text { viscosity } \\
\text { dispersive }\end{array}$ & I & $0.5-1.2 \mathrm{M}$ & $\begin{array}{l}\text { Sodium chloride, sodium } \\
\text { dihydrogen phosphate } \\
\text { dihydrate, dibasic sodium } \\
\text { phosphate hydrate }\end{array}$ & $\begin{array}{l}\text { Seikagaku } \\
\text { Corporation }\end{array}$ \\
\hline OPEGAN Hi ${ }^{\circledR} 0.85 \mathrm{~mL}$ & $\begin{array}{l}10^{5}-10^{6} \\
\text { (hundred } \\
\text { thousands) }\end{array}$ & $\begin{array}{l}\text { Viscous } \\
\text { cohesive }\end{array}$ & I & I.5-3.9 M & $\begin{array}{l}\text { Sodium chloride, sodium } \\
\text { dihydrogen phosphate } \\
\text { dihydrate, dibasic sodium } \\
\text { phosphate hydrate }\end{array}$ & $\begin{array}{l}\text { Seikagaku } \\
\text { Corporation }\end{array}$ \\
\hline Healon $^{\circledR} 0.85 \mathrm{~mL}$ & $\begin{array}{l}10^{5}-10^{6} \\
\text { (hundred } \\
\text { thousands) }\end{array}$ & $\begin{array}{l}\text { Viscous } \\
\text { cohesive }\end{array}$ & I & $1.5-3.9 \mathrm{M}$ & $\begin{array}{l}\text { Sodium chloride, sodium } \\
\text { dihydrogen phosphate } \\
\text { dihydrate, dibasic sodium } \\
\text { phosphate hydrate }\end{array}$ & $\begin{array}{l}\text { Abbott Medical } \\
\text { Optics Inc }\end{array}$ \\
\hline
\end{tabular}

Notes: *From Arshinoff and Jafari. ${ }^{6}$ "From the package insert in Japan. ${ }^{8-10}$

Abbreviations: Conc, concentration; M, million; MW, molecular weight; OVD, ophthalmic viscosurgical device. 


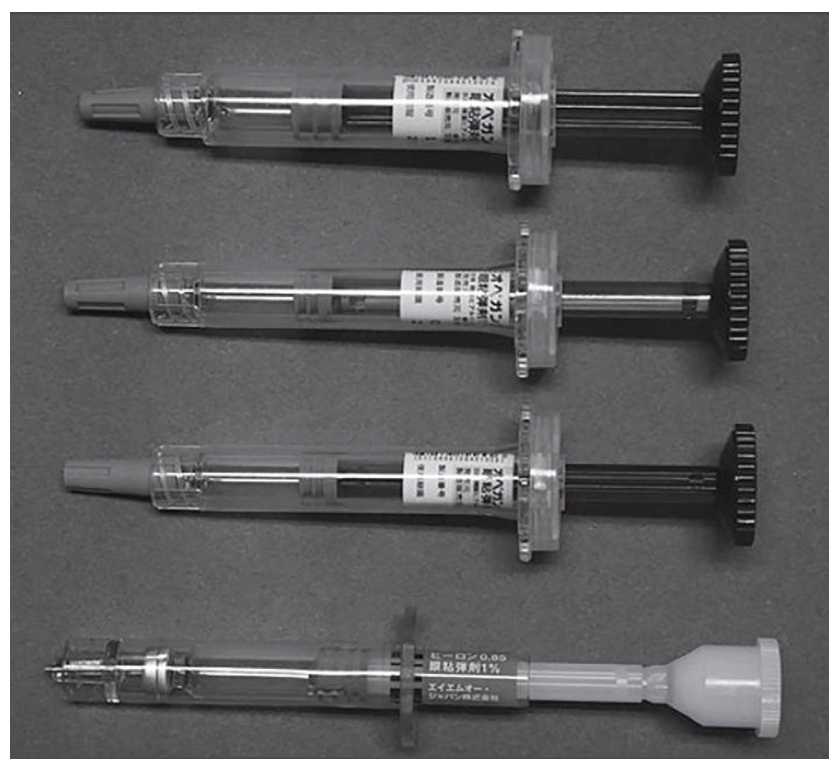

Figure I Investigational products.

Notes: From the top, OPEGAN I.I mL, OPEGAN $0.6 \mathrm{~mL}$, OPEGAN Hi $0.85 \mathrm{~mL}$, Healon $0.85 \mathrm{~mL}$.

Method to refill the syringe

After attaching a needle $22 \mathrm{G} \times 1 \frac{1}{2}$ " (Terumo Corporation) to OPEGAN Hi $0.85 \mathrm{~mL}$ and Healon $0.85 \mathrm{~mL}$, the tip of the needle was inserted into the Luer tip of an empty syringe to refill it with the OVDs. Since a solution with high viscoelasticity was used, it was slowly transferred into the syringe body while avoiding air bubbles from being trapped in the solution. Unused empty $1 \mathrm{~mL}$ syringes were used for refills.

Measurement of the extrusion power

Three samples of both OPEGAN Hi $0.85 \mathrm{~mL}$ and Healon $0.85 \mathrm{~mL}$, which were used to refill the empty syringes (refilled products), were prepared and the extrusion force was measured by the same method described in the "Extrusion force required for each product" section.

\section{Comparison between the prefilled syringes}

The size of the syringe body in contact with the solution and that of the piston attached to the tip of the plunger were measured (Figure 2).

\section{Syringe}

The inner diameter of the syringe body and the inner diameter of the Luer tip were measured. Using the inner diameter, the cross-sectional area of the syringe lumen was calculated as the area of the piston in contact with the solution. Then, the extrusion force applied with the piston against the solution per unit area was calculated among the prefilled syringes.

\section{Piston}

The outer diameter of the piston and the whole length of the piston were measured. Since the surface of the piston in contact with the inner syringe was concavo-convex, the area of the convex portions (peaks) of the piston (contact area) was compared among the refilled syringes. The contact area was calculated by adding each peak (peak width) after measuring the width of each peak of the piston while this was inserted in the syringe chamber, using the following equation:

$$
\mathrm{Ap}=2 \pi(\mathrm{Ds} / 2) \times \mathrm{Wp}
$$

where Ap is contact area, Ds is the inner diameter of the syringe body, and Wp is peak width. For all the measurements,

\section{Luer part}

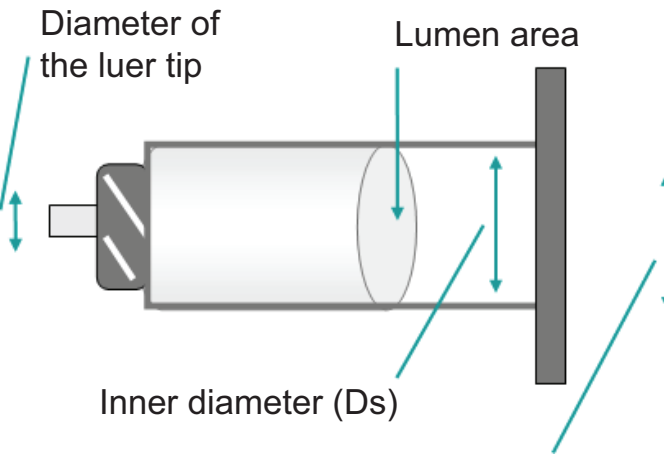

Outer diameter

\section{Piston}

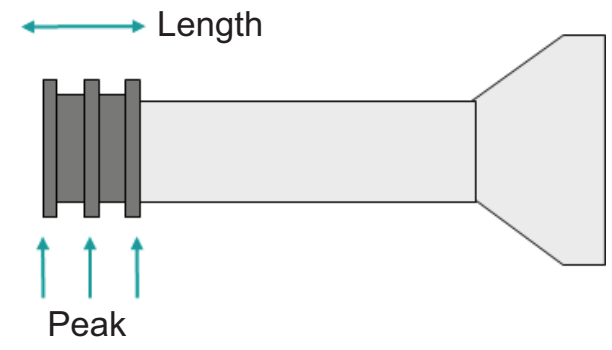

Figure 2 Syringe measurement sites. 


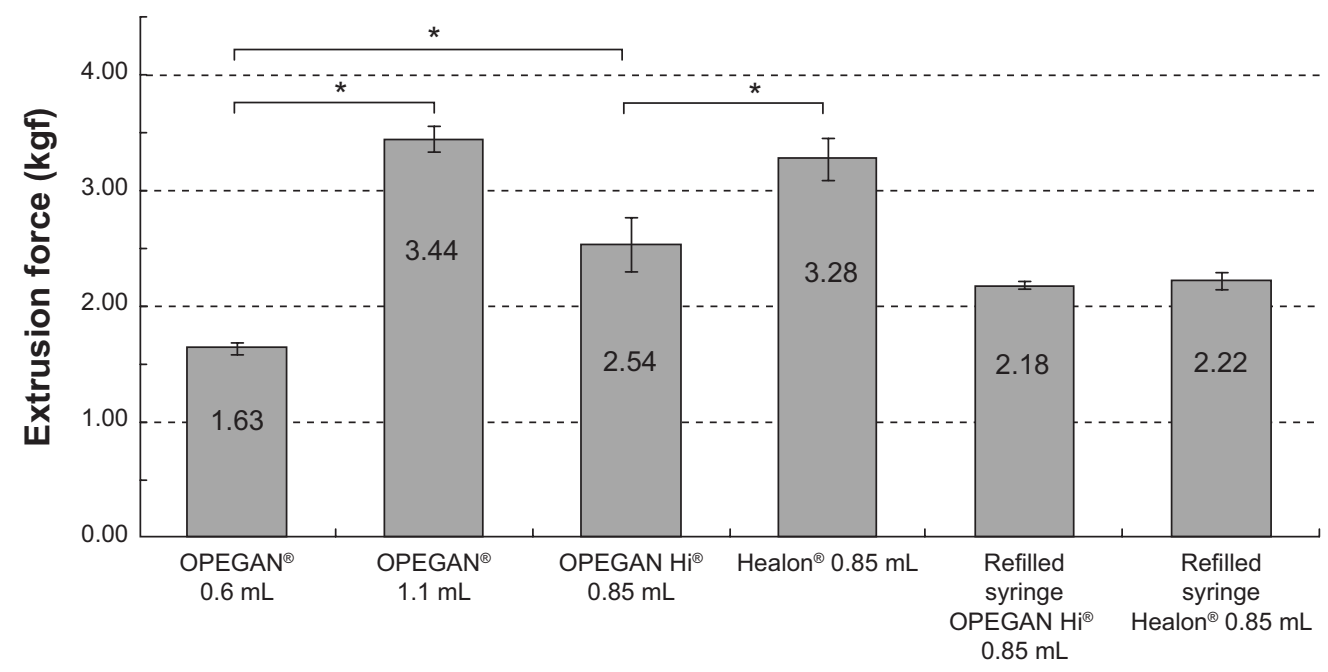

Figure 3 Extrusion force measurement results. Note: $* P<0.0$ I (Student's $t$-test).

the average value was calculated by measuring three samples of each product.

\section{Results}

\section{Extrusion force measurements}

\section{Extrusion force required to deliver each product}

The average measurement of each product is shown in Figure 3.

For OPEGAN Hi $0.85 \mathrm{~mL}$ and Healon $0.85 \mathrm{~mL}$, the extrusion force was $2.54 \pm 0.23 \mathrm{kgf}$ and $3.28 \pm 0.19 \mathrm{kgf}$, respectively, demonstrating a significant difference between them $(P<0.01$, Student's $t$-test). For OPEGAN $0.6 \mathrm{~mL}$ and OPEGAN Hi 0.85 $\mathrm{mL}$, the extrusion force was $1.63 \pm 0.06 \mathrm{kgf}$ and $2.54 \pm 0.23 \mathrm{kgf}$, respectively, also showing a significant difference between them $(P<0.01$, Student's $t$-test). For OPEGAN $0.6 \mathrm{~mL}$ and OPEGAN $1.1 \mathrm{~mL}$, the extrusion force was $1.63 \pm 0.06 \mathrm{kgf}$ and $3.44 \pm 0.12 \mathrm{kgf}$, respectively, showing a significant difference between them $(P<0.01$, Student's $t$-test $)$.

\section{Extrusion force required to deliver refilled products} The average measurements of refilled products are shown in Figure 3.
When syringes of the same type were filled with OPEGAN Hi $0.85 \mathrm{~mL}$ and Healon $0.85 \mathrm{~mL}$ to exclude the factors inherent to the syringes, there were no significant differences in the extrusion forces needed to deliver the contents (Student's $t$-test).

\section{Comparison among prefilled syringes}

Measurements of the syringes are shown in Table 2.

The inner syringe chamber for Healon $0.85 \mathrm{~mL}$ was vial shaped and had a built-in needle in the Luer tip, which was clearly different from that OPEGAN Hi $0.85 \mathrm{~mL}$ (Figure 4). Although the size of the syringe was similar to the $1 \mathrm{~mL}$ syringe used for OPEGAN Hi $0.85 \mathrm{~mL}$, the inner diameter of the syringe for Healon $0.85 \mathrm{~mL}$ was $0.3 \mathrm{~mm}$ larger and the lumen area was approximately $10 \%$ larger than that of the OPEGAN Hi $0.85 \mathrm{~mL}$ syringe. The piston of the Healon $0.85 \mathrm{~mL}$ syringe was also clearly different compared with the $1 \mathrm{~mL}$ syringe used for OPEGAN Hi $0.85 \mathrm{~mL}$; the length of the piston of the Healon $0.85 \mathrm{~mL}$ syringe was longer by $1.8 \mathrm{~mm}$ and it had an extra peak.

In the case of OPEGAN $0.6 \mathrm{~mL}$ and OPEGAN $1.1 \mathrm{~mL}$, the syringe of OPEGAN $1.1 \mathrm{~mL}$ was obviously bigger than

Table 2 Syringe measurement results

\begin{tabular}{|c|c|c|c|c|c|c|c|c|c|}
\hline \multirow[t]{2}{*}{ Products } & \multicolumn{3}{|l|}{ Syringe } & \multicolumn{5}{|l|}{ Piston } & \multirow{2}{*}{$\begin{array}{l}\text { Extrusion } \\
\text { force per } \\
\text { unit area } \\
\left(\mathrm{gf} / \mathrm{mm}^{2}\right)\end{array}$} \\
\hline & $\begin{array}{l}\text { Inner } \\
\text { diameter } \\
(\mathbf{m m})\end{array}$ & $\begin{array}{l}\text { Lumen } \\
\text { area } \\
\left(\mathrm{mm}^{2}\right)\end{array}$ & $\begin{array}{l}\text { Diameter } \\
\text { of the luer } \\
\text { tip }(\mathrm{mm})\end{array}$ & $\begin{array}{l}\text { Outer } \\
\text { diameter } \\
(\mathrm{mm})\end{array}$ & $\begin{array}{l}\text { Length } \\
(\mathrm{mm})\end{array}$ & $\begin{array}{l}\text { Number } \\
\text { of peaks }\end{array}$ & $\begin{array}{l}\text { Peak } \\
\text { width } \\
(\mathrm{mm})\end{array}$ & $\begin{array}{l}\text { Contact } \\
\text { area } \\
\left(\mathrm{mm}^{2}\right)\end{array}$ & \\
\hline OPEGAN ${ }^{\circledR} 0.6 \mathrm{~mL}$ & 6.4 & 31.8 & 1.3 & 6.6 & 6.2 & 3 & 3.1 & 61.3 & 26.6 \\
\hline OPEGAN ${ }^{\circledR} 1.1 \mathrm{~mL}$ & 8.6 & 57.6 & 1.2 & 9.1 & 8.0 & 3 & 3.6 & 95.9 & 35.9 \\
\hline OPEGAN Hi ${ }^{\circledast} 0.85 \mathrm{~mL}$ & 6.4 & 31.8 & 1.3 & 6.6 & 6.2 & 3 & 3.1 & 62.0 & 40.9 \\
\hline Healon ${ }^{\circledast} 0.85 \mathrm{~mL}$ & 6.7 & 35.2 & 0.4 & 7.0 & 8.0 & 4 & 3.4 & 70.8 & 46.3 \\
\hline
\end{tabular}



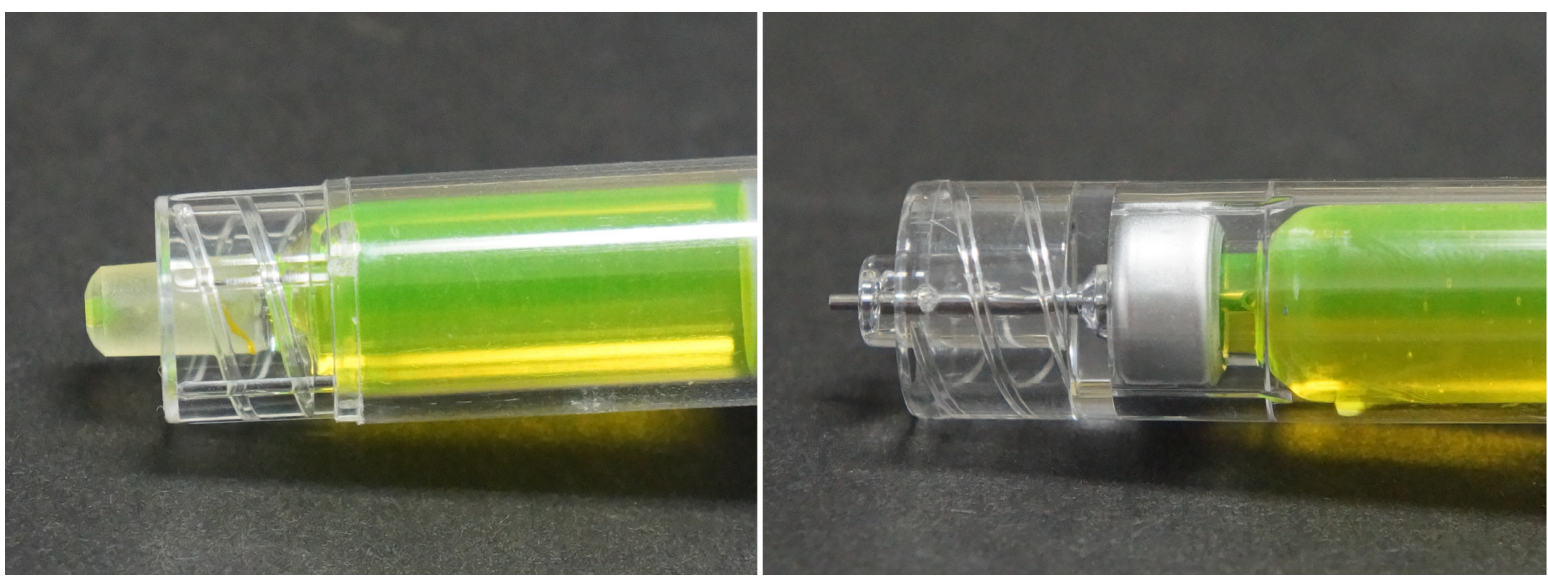

Figure 4 Configuration of the Luer part (in order to enhance the visibility, the colored solution). Left: OPEGAN Hi $0.85 \mathrm{~mL}$; right: Healon $0.85 \mathrm{~mL}$.

that of OPEGAN $0.6 \mathrm{~mL}$. As for OPEGAN Hi $0.85 \mathrm{~mL}$, the syringe was almost the same size as that of OPEGAN $0.6 \mathrm{~mL}$, as well as the concavo-convex-shaped piston, number of peaks, and color. According to the manufacturer, the same $1 \mathrm{~mL}$ syringe was used for OPEGAN $0.6 \mathrm{~mL}$ and OPEGAN Hi $0.85 \mathrm{~mL}$, whereas a $2 \mathrm{~mL}$ syringe was used for OPEGAN $1.1 \mathrm{~mL}$.

\section{Discussion}

Although the major components of OPEGAN Hi $0.85 \mathrm{~mL}$ and Healon $0.85 \mathrm{~mL}$ had the same molecular weight, the extrusion force required for Healon $0.85 \mathrm{~mL}$ was 1.3 -fold of that needed for OPEGAN Hi $0.85 \mathrm{~mL}$. Since they were manufactured by different companies, the configuration of the parts of the syringe was clearly different. In particular, there was a significant difference in the configuration of the Luer tip between OPEGAN Hi $0.85 \mathrm{~mL}$ and Healon $0.85 \mathrm{~mL}$ - a difference of $0.9 \mathrm{~mm}$. Since Healon $0.85 \mathrm{~mL}$ had an approximately $22 \mathrm{G}$ built-in needle, it was considered that passing of the viscoelastic substance through the built-in needle instead of a needle to be attached to the syringe was likely to find more resistance. According to the measurements, there was a difference of $0.3 \mathrm{~mm}$ in the inner diameter of the syringe and the ratio of the lumen area was 1:1.1, indicating a difference of approximately $10 \%$. Additionally, since Healon $0.85 \mathrm{~mL}$ had a longer piston with one extra peak, it was considered that the piston encountered a high resistance; Healon $0.85 \mathrm{~mL}$ had an approximately $10 \%$ larger contact area based on the calculation. In this evaluation, although the highest impact factors were not identified, these slight differences in the parts of the syringe were considered to have influenced the extrusion force.

In fact, there was no significant difference in the extrusion force required to deliver the refilled products when OPEGAN
Hi $0.85 \mathrm{~mL}$ and Healon $0.85 \mathrm{~mL}$ solutions were transferred into the syringes of the same type. These results suggest that the difference in extrusion force between OPEGAN Hi $0.85 \mathrm{~mL}$ and Healon $0.85 \mathrm{~mL}$ was associated with factors inherent to the syringes.

OPEGAN $0.6 \mathrm{~mL}$ and OPEGAN Hi $0.85 \mathrm{~mL}$ showed a 1.6-fold difference in extrusion force. Since both OPEGAN $0.6 \mathrm{~mL}$ and OPEGAN Hi $0.85 \mathrm{~mL}$ were each filled into $1 \mathrm{~mL}$ syringes under the same conditions, the difference in extrusion forces was considered to be due to the difference in the molecular weight of the product or in the viscoelasticity of these OVDs.

On the other hand, even though OPEGAN $0.6 \mathrm{~mL}$ and OPEGAN $1.1 \mathrm{~mL}$ were manufactured by the same company and met the same standards, there was a 2.1-fold difference in the extrusion force. As there was a difference of $2.2 \mathrm{~mm}$ in the inner diameter of the syringe, the ratio of the lumen area of OPEGAN $0.6 \mathrm{~mL}$ to that of OPEGAN $1.1 \mathrm{~mL}$ was $1: 1.8$, meaning that the OVD in OPEGAN $0.6 \mathrm{~mL}$ receives a 1.8-fold force per unit area compared with OPEGAN $1.1 \mathrm{~mL}$, requiring a lower extrusion force. Additionally, the ratio of the contact area of the piston, which is prone to develop sliding resistance, was 1:1.6, indicating that the contact area of the OPEGAN $0.6 \mathrm{~mL}$ syringe was smaller than that of the OPEGAN $1.1 \mathrm{~mL}$ syringe; therefore, the former was considered to exert less resistance when the content was delivered.

Although OPEGAN $0.6 \mathrm{~mL}$ and OPEGAN $1.1 \mathrm{~mL}$ were manufactured by the same company and met the same standards, the difference in usability between them was due to the size of the syringe used and the difference in the size of these syringes was reflected in the difference in extrusion force. Consequently, the bigger the syringe, the higher the required extrusion force. 
The extrusion force of OVDs were measured to conduct a comparative review of the configuration of syringes as a main factor of the extrusion force unrelated to the viscoelasticity of the OVDs. These results show that when the same syringe is used, the OVD with the higher molecular weight or higher frequency viscoelasticity requires a higher extrusion force; on the other hand, when different syringes are used, their characteristics are totally reflected in the extrusion force. Specifically, based on the assumption that other factors remain the same, when a larger syringe with a larger inner diameter is used, the force against the OVD per unit area is smaller, the piston is larger, the resistance is higher, and the required extrusion force is higher. When a syringe with a smaller Luer tip is used, the resistance is higher and the required extrusion force is also higher.

\section{Conclusion}

In this study, it was confirmed that the configuration of the syringes is another determinant of the extrusion force. The differences in the configuration of syringes factor into the differences in usability of OVDs that meet the same cohesive class. Since the surgeons who perform precise surgeries such as intraocular surgery sometimes experience this difference in usability, understanding that drug properties as well as the configuration of syringes can cause this difference should contribute to further improvement of these devices.

\section{Disclosure}

The authors report no conflicts of interest in this work.

\section{References}

1. Hütz WW, Eckhardt HB, Kohnen T. Comparison of viscoelastic substances used in phacoemulsification. J Cataract Refract Surg. 1996; 22(7):955-959.

2. Arshinoff SA. New terminology: ophthalmic viscosurgical devices. $J$ Cataract Refract Surg. 2000;26(5):627-628.

3. Tetz MR, Holzer MP, Lundberg K, Auffarth GU, Burk RO, Kruse FE. Clinical results of phacoemulsification with the use of Healon 5 or Viscoat. J Cataract Refract Surg. 2001;27(3):416-420.

4. Arshinoff SA. Using BSS with viscoadaptives in the ultimate soft-shell technique. J Cataract Refract Surg. 2002;28(9):1509-1514.

5. Budo C, Goffinet G, Bellotto D, Petroll WM. Effect of ophthalmic viscosurgical devices on lens epithelial cells: a morphological study. J Cataract Refract Surg. 2003;29(12):2411-2418.

6. Arshinoff SA, Jafari M. New classification of ophthalmic viscosurgical devices - 2005. J Cataract Refract Surg. 2005;31(11):2167-2171.

7. Arshinoff SA, Norman R. Tri-softshell technique. J Cataract Refract Surg. 2013;39(8):1196-1203.

8. OPEGAN [package insert]. Tokyo, Japan: Seikagaku Corporation; 2014.

9. OPEGAN Hi [package insert]. Tokyo, Japan: Seikagaku Corporation; 2014.

10. Healon [package insert]. Santa Ana, CA, USA: Abbott Medical Optics Inc;2010.
Clinical Ophthalmology

\section{Publish your work in this journal}

Clinical Ophthalmology is an international, peer-reviewed journal covering all subspecialties within ophthalmology. Key topics include: Optometry; Visual science; Pharmacology and drug therapy in eye diseases; Basic Sciences; Primary and Secondary eye care; Patient Safety and Quality of Care Improvements. This journal is indexed on

Submit your manuscript here: http://www.dovepress.com/clinical-ophthalmology-journal

\section{Dovepress}

PubMed Central and CAS, and is the official journal of The Society of Clinical Ophthalmology (SCO). The manuscript management system is completely online and includes a very quick and fair peer-review system, which is all easy to use. Visit http://www.dovepress.com/ testimonials.php to read real quotes from published authors. 